\title{
GRASSLAND RANGES \\ in the southern interior of British Columbia
}

CANADA DEPARTMENT OF AGRICULTURE PUBLICATION 13191968

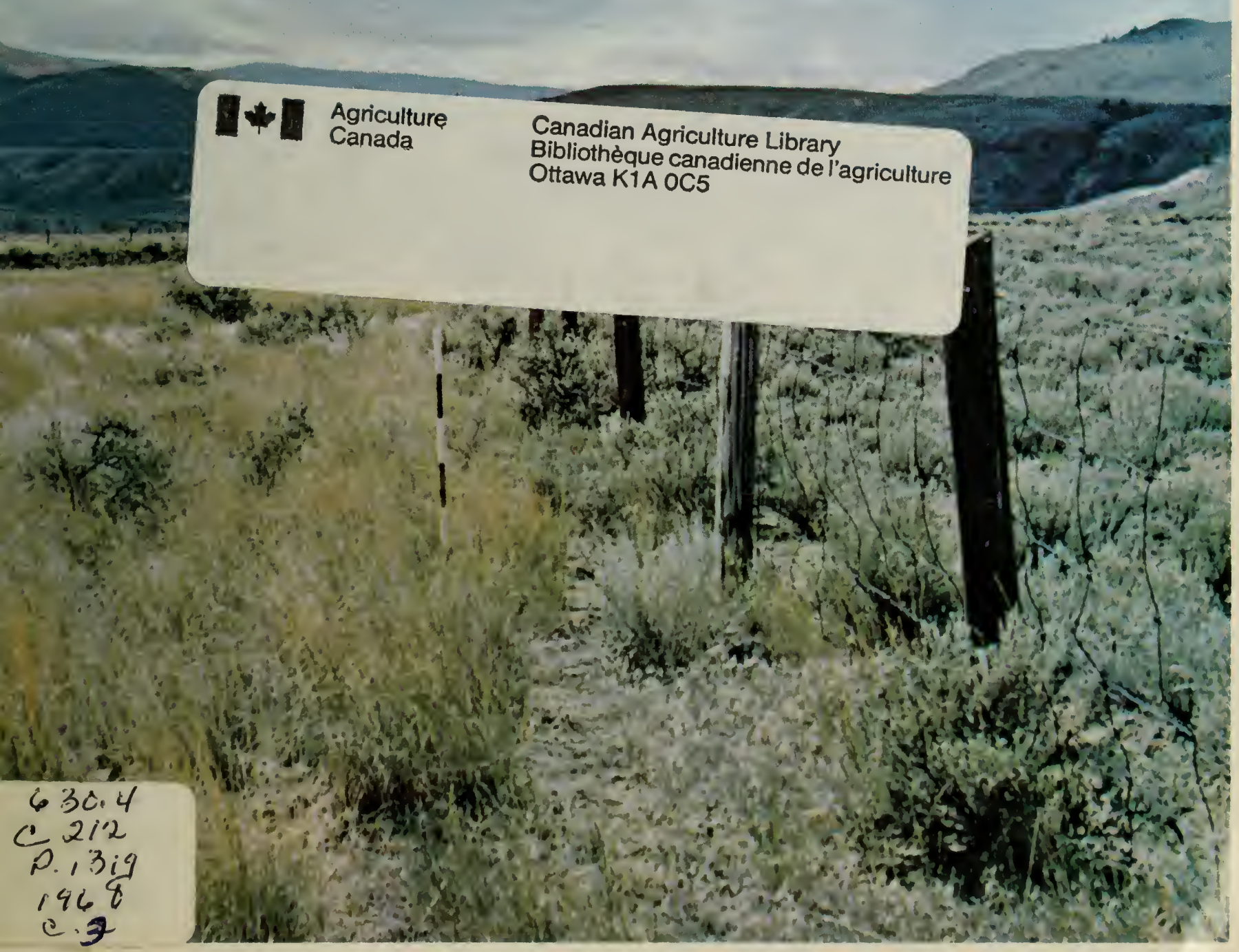




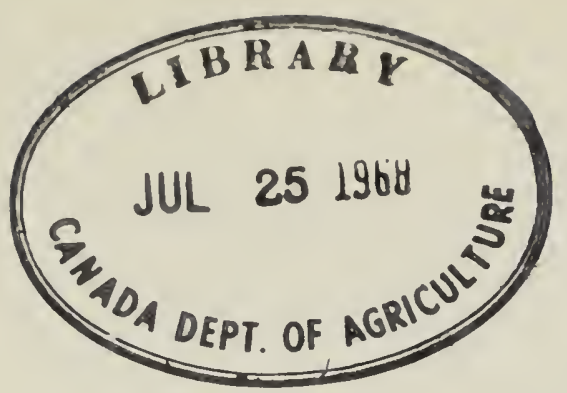




\title{
GRASSLAND RANGES \\ In the Southern Interior of British Columbia
}

\author{
ALASTAIR MCLEAN AND LEONARD MARCHAND \\ Research Station, Kamloops, B.C.
}

\section{GUIDE TO TYPES AND CONDITIONS OF RANGES}

A successful range manager should

- be able to recognize the types of forage on his range;

- know something of the quality and quantity of forage each of his range types is capable of producing;

- be able to appraise the condition of the range in relation to its potential.

A range site, in terms of range management, is an area of rangeland that has a certain potential for growing forage. The potential depends on the soil, climate, and slope, and is achieved by the climax plant community characteristic of the site.

Range condition is the state or health of a range in relation to its potential. It depends on the responses of forage cover and soil to grazing practices. It is determined by observing the species, the relative abundance and vigor of the plants, and the amount of litter or mulch on the ground, and the degree of erosion. In British Columbia the condition is a measure of forage production in relation to the potential under ungrazed or climax vegetation or ideal management.

A climax plant community is one in which the plant species have reached a state of equilibrium with the climate and soil.

Plant succession is the replacement of one plant species or group of species by others. The changes may result from disturbances caused by animals or man, changes in the climate or soil, or changes wrought by the plants themselves. Plant succession may be detrimental or beneficial, depending on the land use. There are many stages of succession and these may vary depending on what is causing the change.

Range plants can be classified according to their response to grazing. The classes, as defined by the United States Department of Agriculture (Agricultural Handbook 235), are decreasers, increasers, and invaders. In rating ranges as to condition the following classes are standard: excellent, good, fair, and poor. These classes reflect the relative amounts of desirable or climax forage plants (decreasers) compared with less desirable species (increasers) and weeds (invaders), mostly annuals.

Decreasers are species that decrease under prolonged, excessive grazing. Usually they are perennials that produce much high-quality forage, and dominate the climax community. In determining the range condition class, the total of all such species present is tallied. 
Increasers are species that increase with moderate overuse; they decrease with continued heavy overuse. Increasers commonly are the shorter, less productive, subdominant species in the climax plant community. Their forage value ranges from low to high. Under grazing, those of low forage value tend to increase more rapidly than those of high value.

Invaders are species that invade the plant community as a range deteriorates. They are not members of the climax plant community for the range site since they cannot withstand the competition for moisture, nutrients, and light in the climax vegetation. They come in and grow along with the increasers after the preferred species have been destroyed by grazing. Invaders need not be exotics since they may be members of the climax plant communities on other range sites in the same locality. Some are annual weeds and herbaceous perennials and some are woody shrubs; many have some grazing value but others have little.

Excellent range has at least 75 percent of the forage made up of decreasers. The plants are vigorous, have good root systems, and set a good crop of viable seed in most years. There is enough mulch on the ground to prevent erosion, conserve soil moisture, and prevent winter-killing of plants. The total amount of mulch varies considerably with the site, but the relative amount for each class generally does not. Rain soaks in rapidly. Erosion is not useful as a criterion of excellent range on nearly flat land or on soils that resist erosion.

Good range has 50 to 75 percent of the forage made up of decreasers. The plants are vigorous and set an adequate crop of viable seed in most years. There is enough mulch to allow little erosion. Rain soaks in fairly rapidly.

Fair range has from 25 to 50 percent of the forage made up of decreasers, the rest made up of increasers, many of which are unpalatable. Some invaders are usually present. The decreaser plants lack vigor, have some killing at the crowns, and set adequate seed crops in fewer than half the years. There is not usually enough mulch to prevent erosion. The amount of mulch is not a useful criterion of fair range if the range has had good management for a few years but not long enough to change the plant species present. Rainfall soaks in poorly, causing considerable runoff and some sheet erosion.

Poor range has less than 25 percent of its forage made up of decreasers, and those present are generally in a weakened condition. Invaders and unpalatable increasers are abundant. Very little mulch is present, water runoff is frequent, and the topsoil is generally compacted. Sheet and rill erosion is usually marked.

Stocking rates in this publication have been estimated on the basis of acres per animal-unit 'month (AUM), this being the number of acres needed to graze a 1000-pound cow for 1 month. They cannot be determined directly from the estimated total forage yields. The amount of available forage has to be calculated, a 45 percent carryover being allowed to avoid damage to the range. On the average, about 660 pounds of available forage is needed per AUM. Other factors such as stocking history, livestock grazing habits, season of grazing, kind of 
livestock, distance of water, steepness of slope, rockiness, and palatability or nutritive value of the forage must also be considered.

The following are commonly accepted animal-unit equivalents: yearling, 0.6 ; bull, 1.3 ; horse, 1.5 ; ewe, 0.2 .

Range trend, that is, whether the range is improving or deteriorating, should be determined along with range condition. The following criteria should be used: the degree of use, or percentage carryover of forage; the plant species that are reproducing and becoming established; the relative vigor of desirable and undesirable species; and erosion signs, healing over of gullies, evidence of soil puddling, and accumulation of mulch.

The botanical and common names of plants are listed in Tables 1, 2, 3, and 4 .

Caution: The classifications listed in this publication are to some degree an oversimplification of the plant communities as you will find them. For example, you will find many situations that are intermediate between the types and classes recorded. Other sites, because of a peculiar climate or a soil that is especially shallow, sandy, salty, or rocky, will not conform to the pattern or will be unable to reach the potential indicated. There is no substitution for careful observation and sound reasoning and judgment in the application of the principles given in this publication.

\section{Big Sagebrush - Bluebunch Wheatgrass Site}

\section{ELEVATION}

1100 to 2000 feet near Kamloops; often different in other areas.

\section{PRECIPITATION}

Nine to 10 inches per year, slightly more than half falling from April to the end of October.

\section{TEMPERATURE}

From a high monthly mean of $73^{\circ} \mathrm{F}$ (July) to a low mean of $23^{\circ} \mathrm{F}$ (January); yearly mean is $48^{\circ} \mathrm{F}$.

The summers are hot and dry with occasional storms. The winters do not usually have prolonged cold spells; snowfall is rather light, and occasional chinook winds bare the ground and may be followed by drying winds. March and April are usually dry and windy.

\section{TOPOGRAPHY}

From nearly level to rolling and very steep with small benches and deep gullies. Most of these grasslands are on outwash plains and terraces on the drier valley slopes.

SOILS

Brown, medium textured, neutral to slightly saline. Lime is generally found at about 1 foot. 


\section{GRAZING USE}

Early spring, late fall, and winter range.

\section{GROWING SEASON}

Mid-March to end of June. In most years there is only a small amount of regrowth in the fall.

\section{NATIVE VEGETATION}

\section{Decreasers}

Bluebunch wheatgrass

Needle-and-thread

(some soils)

\section{Increasers}

Big sagebrush

Dwarf pussytoes

Needle-and-thread

Rabbitbrush

Sand dropseed (sandy soils)

Sandberg's bluegrass
Invaders

Tansy mustard

Downy brome

Russian thistle

These grasslands are distinguished by the presence of big sagebrush, wellspaced bunchgrasses with bare ground between plants, and relatively few plant species. With overgrazing, bluebunch wheatgrass is replaced by Sandberg's bluegrass and big sagebrush.

Under prolonged misuse, annuals become abundant. On some dry sites, needle-and-thread may be an important increaser until grazing becomes severe and it is forced out. It occurs in varying proportions with bluebunch wheatgrass.

Needle-and-thread forms a climax and with big sagebrush becomes a decreaser on some coarse-textured soils. On the basis of forage yield and plant composition, however, such sites still fit into the condition classes as established. Range dominated by needle-and-thread is not considered excellent range under any conditions; this grass yields less than bluebunch wheatgrass and may injure the mouths of grazing animals because of the barbed seeds and long awns if it is grazed after seed is formed and before it is shed. As big sagebrush-needleand-thread range deteriorates, sand dropseed and big sagebrush increase at the expense of the needle-and-thread. Since the needle-and-thread climax sites are usually inherently less productive than the bluebunch wheatgrass sites, the amount of big sagebrush present is usually less for the same condition class.

\section{CONDITION CLASSES}

The percentages of ground cover for the main plants by classes are:

Plants

Decreasers

Increasers

Big sagebrush

Total

\section{Excellent}

60

$0-15$

0-30
Good

60-40

15-30

30-50
Fair

40-20

30-45

50-70
Poor

20-0

45-60

70

(Amounts of big sagebrush are usually about 10 percent less for the same condition class on needle-and-thread sites) 


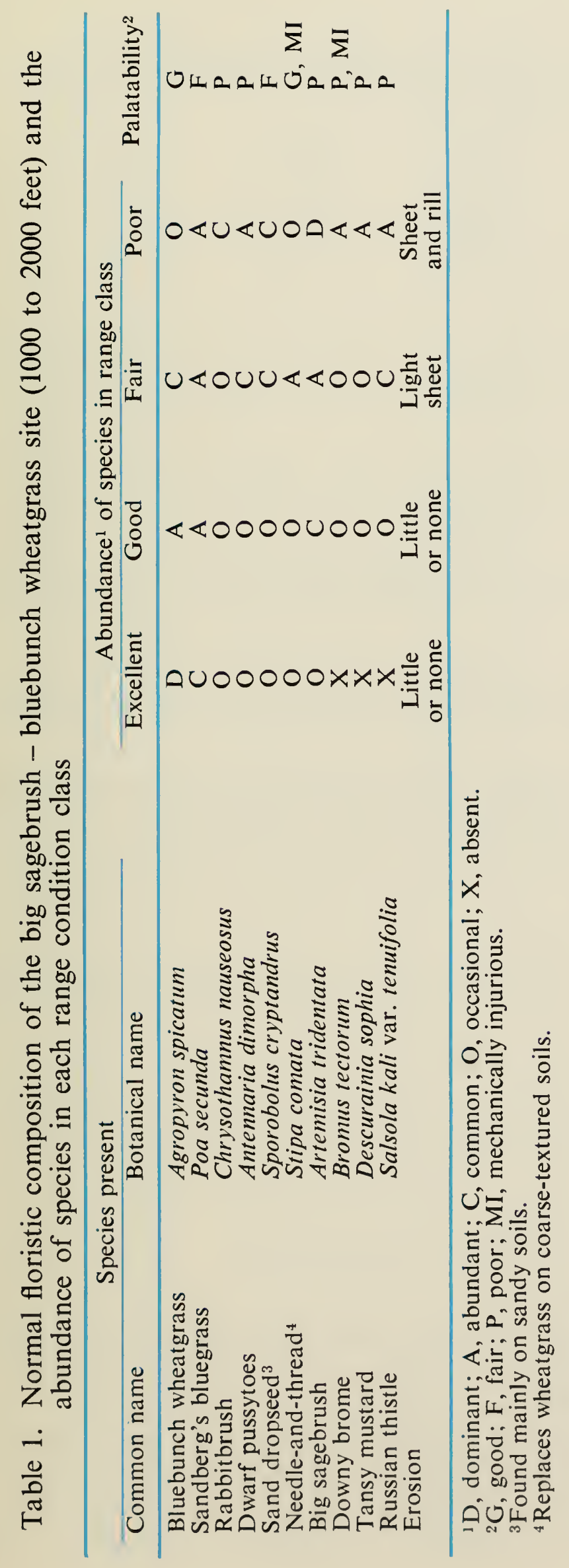




\section{FORAGE YIELDS}

The yields (pounds per acre) and average stocking rates (acres per AUM) for the four classes of condition are:

$\begin{array}{lcccc} & \text { Excellent } & \text { Good } & \text { Fair } & \text { Poor } \\ \text { Yield, average } & 550 & 400 & 250 & 100 \\ \text { Yield, range } & 900-400 & 700-250 & 400-150 & 250-50 \\ \text { Percentage of potential } & 100 & 73 & 46 & 18 \\ \text { Stocking rate } & 2.2 & 3.0 & 4.8 & 12.0\end{array}$

\section{Bluebunch Wheatgrass - Sandberg's Bluegrass Site}

\section{ELEVATION}

2000 to 2600 feet near Kamloops; often different in other areas.

\section{PRECIPITATION}

Ten to 11.5 inches per year, slightly more than half falling from April to the end of October.

\section{TEMPERATURE}

From a high monthly mean of $70^{\circ} \mathrm{F}$ (July) to a low mean of $22^{\circ} \mathrm{F}$ (January); yearly mean is $47^{\circ} \mathrm{F}$.

As the elevation increases, mean temperatures and evaporation decrease and moisture effectiveness increases. Winter cold spells are more prolonged and drying winter winds more common than in the big sagebrush-bluebunch wheatgrass grasslands.

\section{TOPOGRAPHY}

From nearly level to rolling and steep, often with hummocky microtopography.

\section{SOILS}

Dark Brown, medium light textured, neutral to slightly saline. Lime is generally found at about 1.5 feet.

GRAZING USE

Spring and fall (early May and October) range.

\section{GROWING SEASON}

Late March to early July. In most years there is some fall regrowth.

\section{CONDITION CLASSES}

The percentages of ground cover for the main plants by classes are:

$\begin{array}{lcccc}\text { Plants } & \text { Excellent } & \text { Good } & \text { Fair } & \text { Poor } \\ \text { Decreasers } & 60 & 60-40 & 40-20 & 20-0 \\ \text { Increasers } & 0-30 & 30-50 & 50-70 & 70\end{array}$




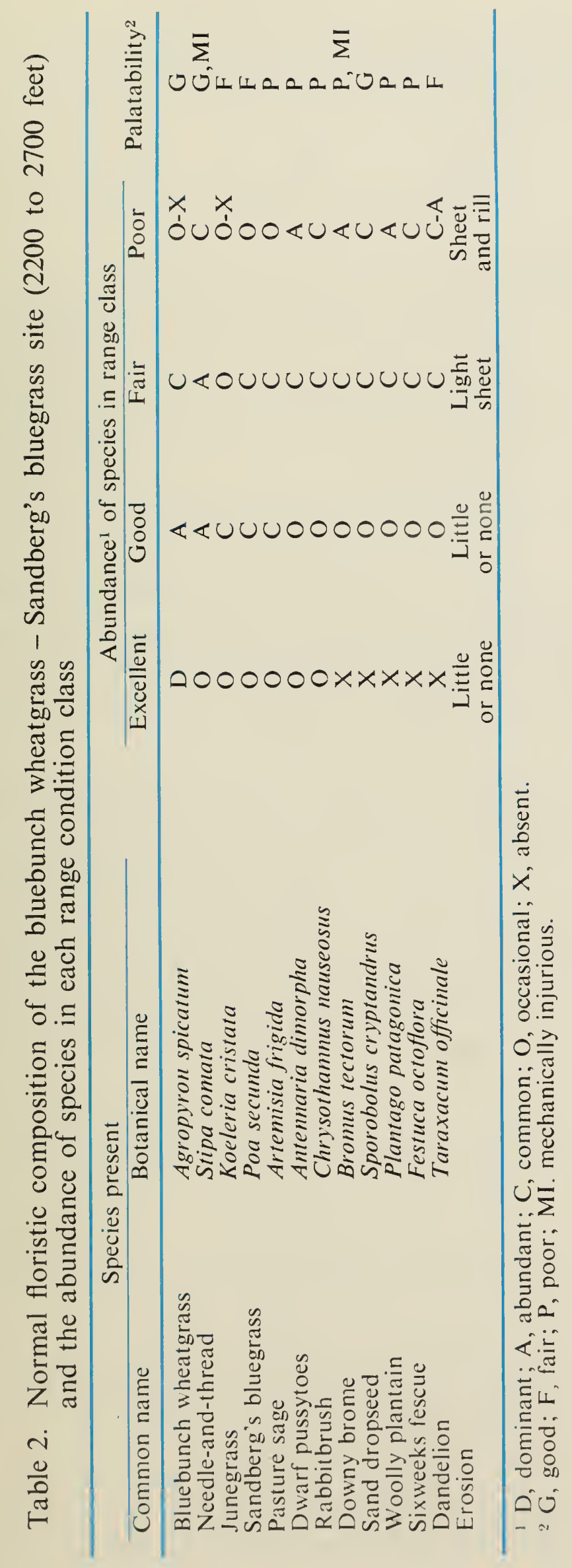




\section{FORAGE YIELDS}

The yields (pounds per acre) and average stocking rates (acres per AUM) for the four classes of condition are:

$\begin{array}{lcccc} & \text { Excellent } & \text { Good } & \text { Fair } & \text { Poor } \\ \text { Yield, average } & 500 & 420 & 325 & 250 \\ \text { Stocking rate } & 2.4 & 2.9 & 3.7 & 4.8\end{array}$

NATIVE VEGETATION

Decreasers

Bluebunch wheatgrass

Needle-and-thread

(some soils)

Increasers
Dwarf pussytoes
Junegrass
Needle-and-thread
Pasture sage
Rabbitbrush
Sand dropseed (sandy soils)
Sandberg's bluegrass

Increasers

Invaders

Downy brome

Dandelion

Sixweeks fescue

Woolly plantain

The absence of big sagebrush and closer spacing of the plants distinguish this site from the big sagebrush-bluebunch wheatgrass site; the dominance of bunchgrasses as compared with forbs, the absence of aspen clumps, and the presence of only a few species distinguish it from the bluebunch wheatgrass rough fescue site.

Under misuse, needle-and-thread usually becomes dominant but is replaced in turn by downy brome and low-growing weeds. Needle-and-thread may form a climax and become a decreaser on certain coarse-textured soils. However, on the basis of forage yield and species composition such sites fit into the condition classes as established. Range dominated by needle-and-thread is not usually considered excellent range; this grass yields less than bluebunch wheatgrass and may injure the mouths of grazing animals because of the barbed seeds and long awns if it is grazed after seed is formed and before it is shed.

\section{Bluebunch Wheatgrass - Rough Fescue Site}

\section{ELEVATION}

2600 to 3000 feet near Kamloops; often different in other areas.

\section{PRECIPITATION}

Eleven to 13 inches per year, slightly more than half falling from April to the end of October.

\section{TEMPERATURE}

From a high monthly mean of $66^{\circ} \mathrm{F}$ (July) to a low mean of $20^{\circ} \mathrm{F}$ (January); yearly mean is $45^{\circ} \mathrm{F}$. As the elevation increases, mean temperatures and evapora- 
tion decrease and moisture effectiveness increases. Winter cold spells are more prolonged and drying winds less common than in the bluebunch wheatgrass Sandberg's bluegrass site. The ground is seldom bared of snow during the winter.

\section{TOPOGRAPHY}

From nearly level to rolling, sometimes steep.

\section{SOILS}

Dark Brown to Black, usually neutral in reaction and medium textured. Lime is generally found at about 2 feet.

GRAZING USE

Spring and fall (late May, June, and October) range.

\section{GROWING SEASON}

First week in April to mid-July. In most years there is also considerable regrowth in September.

\section{CONDITION CLASSES}

The percentages of ground cover for the main plants by classes are:

$\begin{array}{lcccl}\text { Plants } & \text { Excellent } & \text { Good } & \text { Fair } & \text { Poor } \\ \text { Decreasers } & 60 & 60-40 & 40-20 & 20-0 \\ \text { Increasers } & 0-30 & 30-50 & 50-70 & 70\end{array}$

\section{FORAGE YIELDS}

The yields (pounds per acre) and average stocking rates (acres per AUM) for the four classes of condition are:

$\begin{array}{lcccc} & \text { Excellent } & \text { Good } & \text { Fair } & \text { Poor } \\ \text { Yield, average } & 1000 & 800 & 700 & 500 \\ \text { Yield, range } & 426-2278 & 412-1866 & 420-1339 & 368-854 \\ \text { Percentage of potential } & 100 & 80 & 70 & 50 \\ \text { Stocking rate } & 1.2 & 1.5 & 1.7 & 2.2\end{array}$

\section{NATIVE VEGETATION}

Decreasers

Bluebunch wheatgrass

Idaho fescue

Rough fescue
Increasers

Columbia needlegrass

Junegrass

Kentucky bluegrass

Pasture sage

Pussytoes

Sandberg's bluegrass

Silky lupine

Timber milk-vetch

Western yarrow
Invaders

Downy brome

Dandelion

Common mullein

Compound

fleabane

This site is distinguished by more species and greater abundance of forbs, increased height growth of grasses, and more dense plant cover than the other 


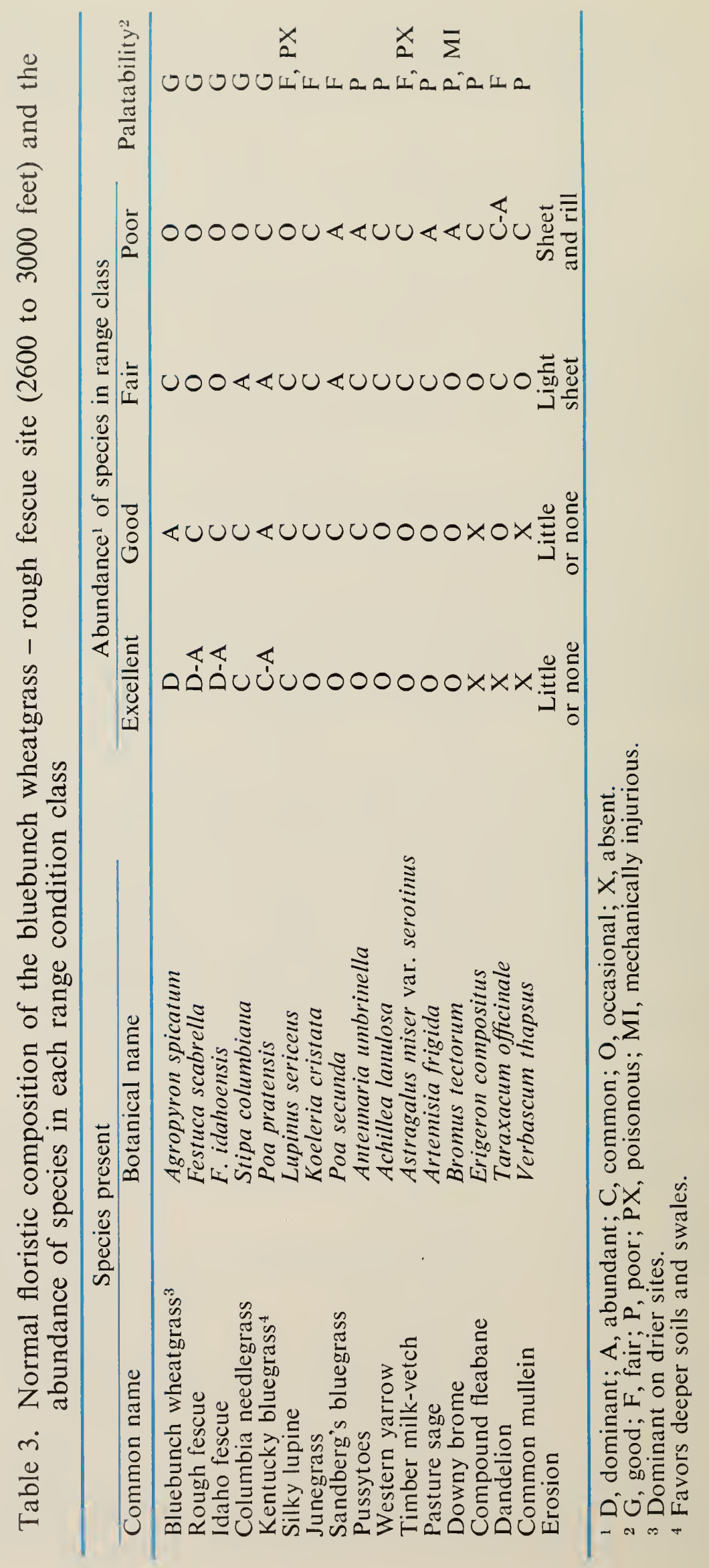


two zones. Clumps of aspen occur frequently in draws and swales. With overgrazing the decreasers are replaced normally by Sandberg's bluegrass and weedy species such as compound fleabane, pasture sage, pussytoes, western yarrow, dandelion, and common mullein. Downy brome and other annuals increase greatly on range in poor condition. The zone lies adjacent to the Douglas fir forest. On certain range sites in fair condition needle-and-thread and Columbia needlegrass increase but decrease again with prolonged misuse.

Idaho fescue replaces rough fescue to a great extent in the Similkameen and Kettle valleys and southern part of the Rocky Mountain Trench. The fescues generally increase on the more moist upland sites within the zone as compared with bluebunch wheatgrass, and are confined largely to the north- and eastfacing slopes in the lower parts of the zone. Kentucky bluegrass generally dominates on deep, fine-textured soils and swales but frequently increases in the bluebunch wheatgrass - rough fescue community as the latter deteriorates with grazing pressure.

\section{Ponderosa Pine Site}

\section{ELEVATION}

2000 to 3000 feet near Kamloops; often different in other areas.

\section{PRECIPITATION}

Eleven to 13 inches, slightly over half falling from April to the end of October.

\section{TEMPERATURE}

Approximately the same climatic regime as the middle grasslands and lower portion of the bluebunch wheatgrass - rough fescue grasslands.

\section{TOPOGRAPHY}

From nearly level to rolling, sometimes steep.

\section{SOILS}

Brown Wooded or Dark Gray, neutral in reaction, and generally light textured. Often on duny sands and outwash gravel terraces.

\section{GRAZING USE}

Spring and fall (May, June, and October).

\section{GROWING SEASON}

Late March to end of June. In most years there is considerable regrowth in September.

\section{CONDITION CLASSES}

The percentages of ground cover for the main plants by classes are:

$\begin{array}{lcccc}\text { Plants } & \text { Excellent } & \text { Good } & \text { Fair } & \text { Poor } \\ \text { Decreasers } & 60 & 60-40 & 40-20 & 20-0 \\ \text { Increasers } & 0-30 & 30-50 & 50-70 & 70\end{array}$




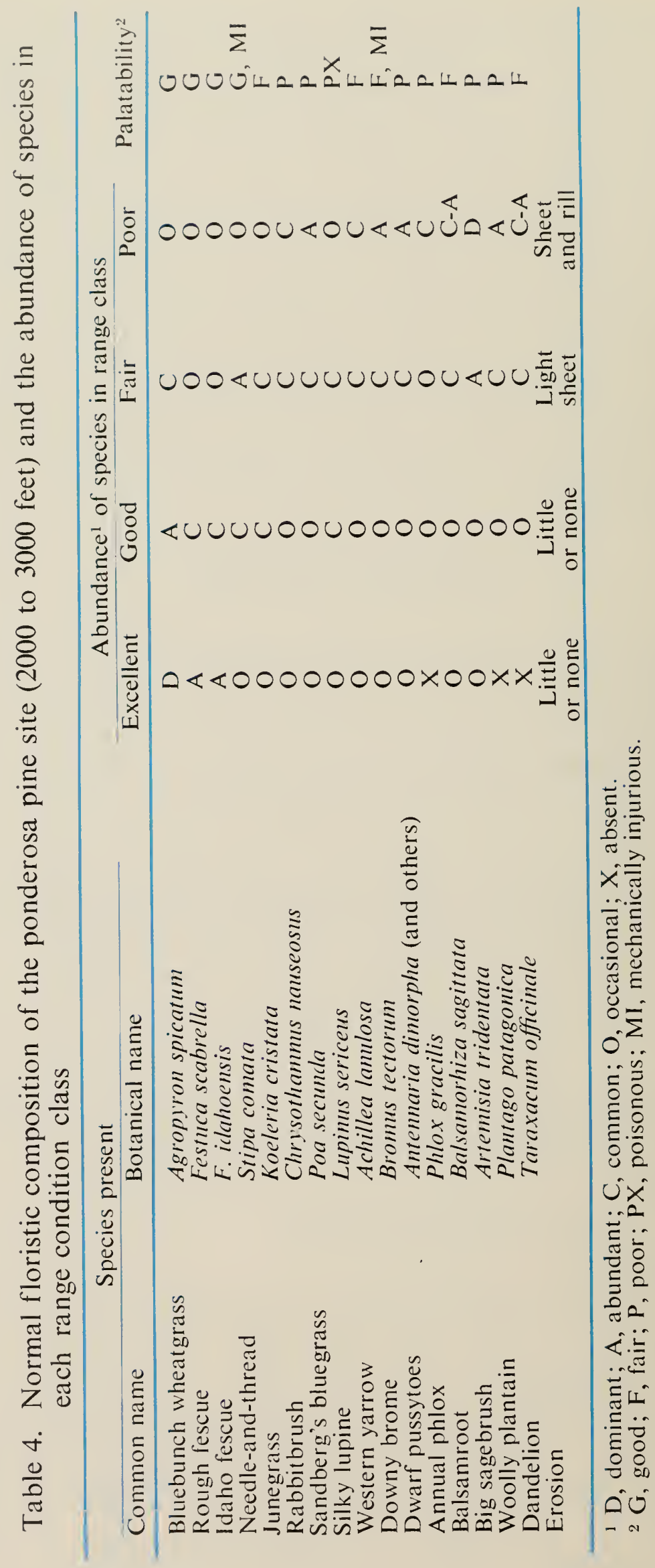




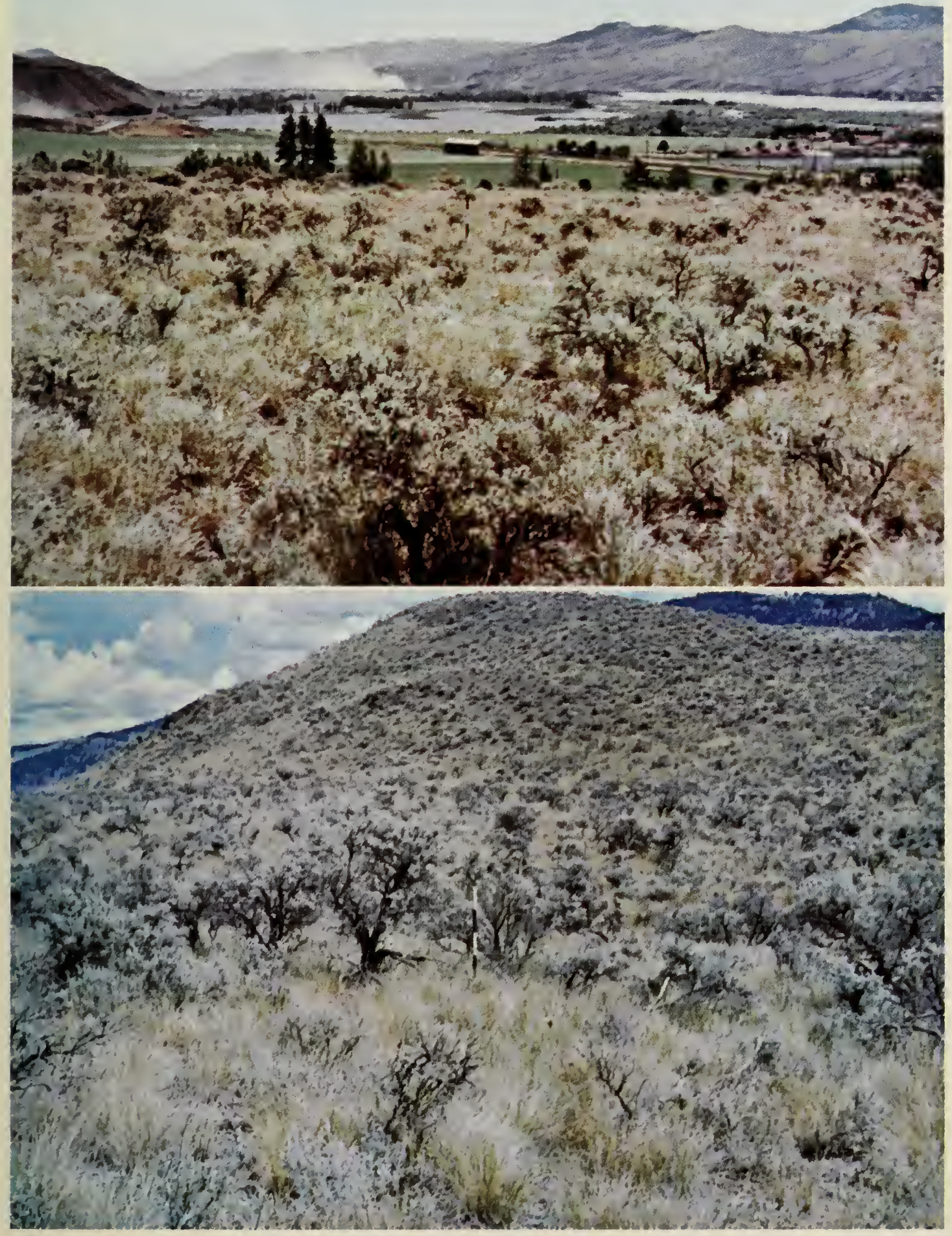

Big sagebrush - bluebunch wheatgrass condition classes. Top, excellent. Bottom, good. 

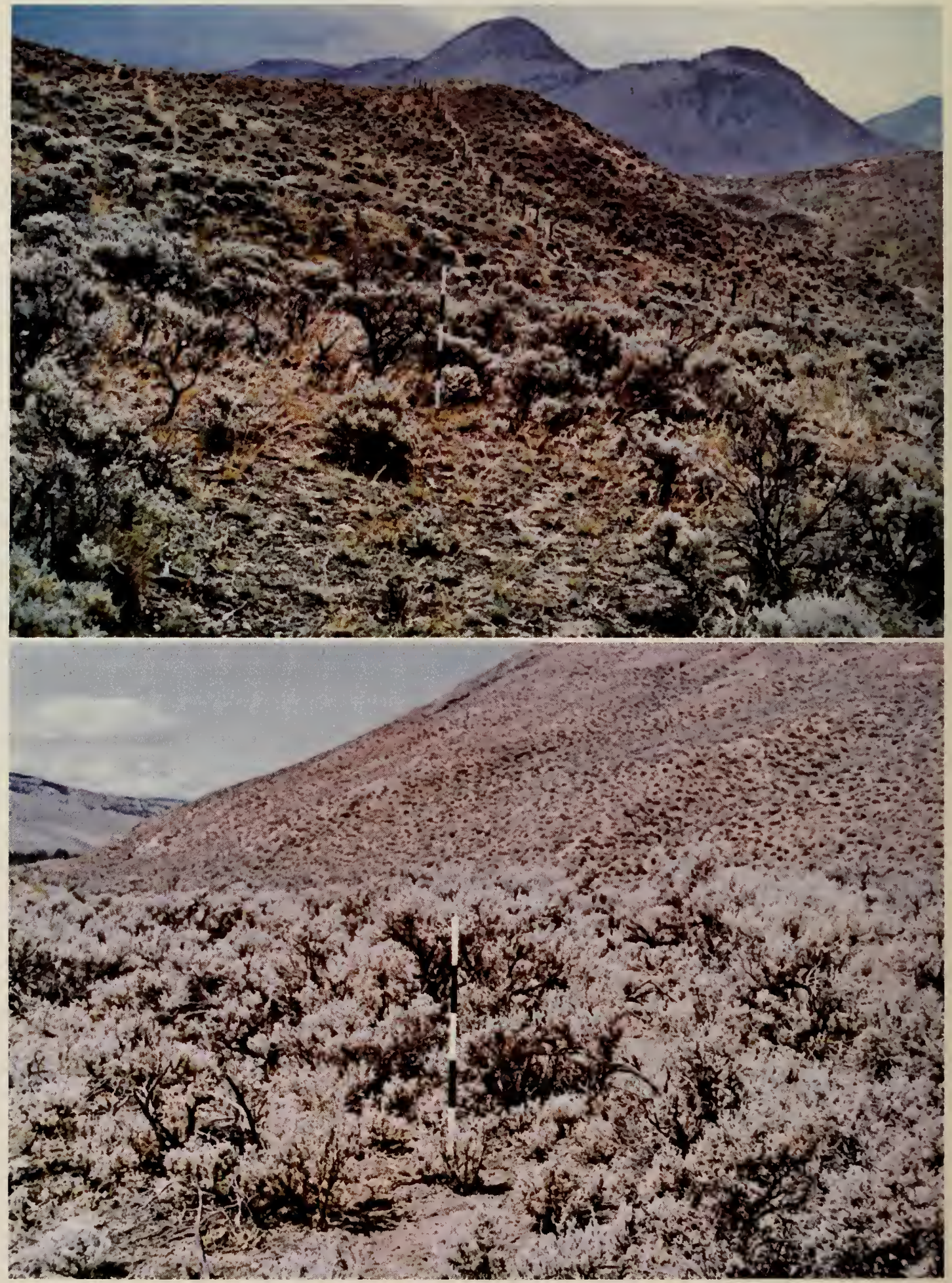

Big sagebrush - bluebunch wheatgrass condition classes. Top, fair. Bottom, poor. 


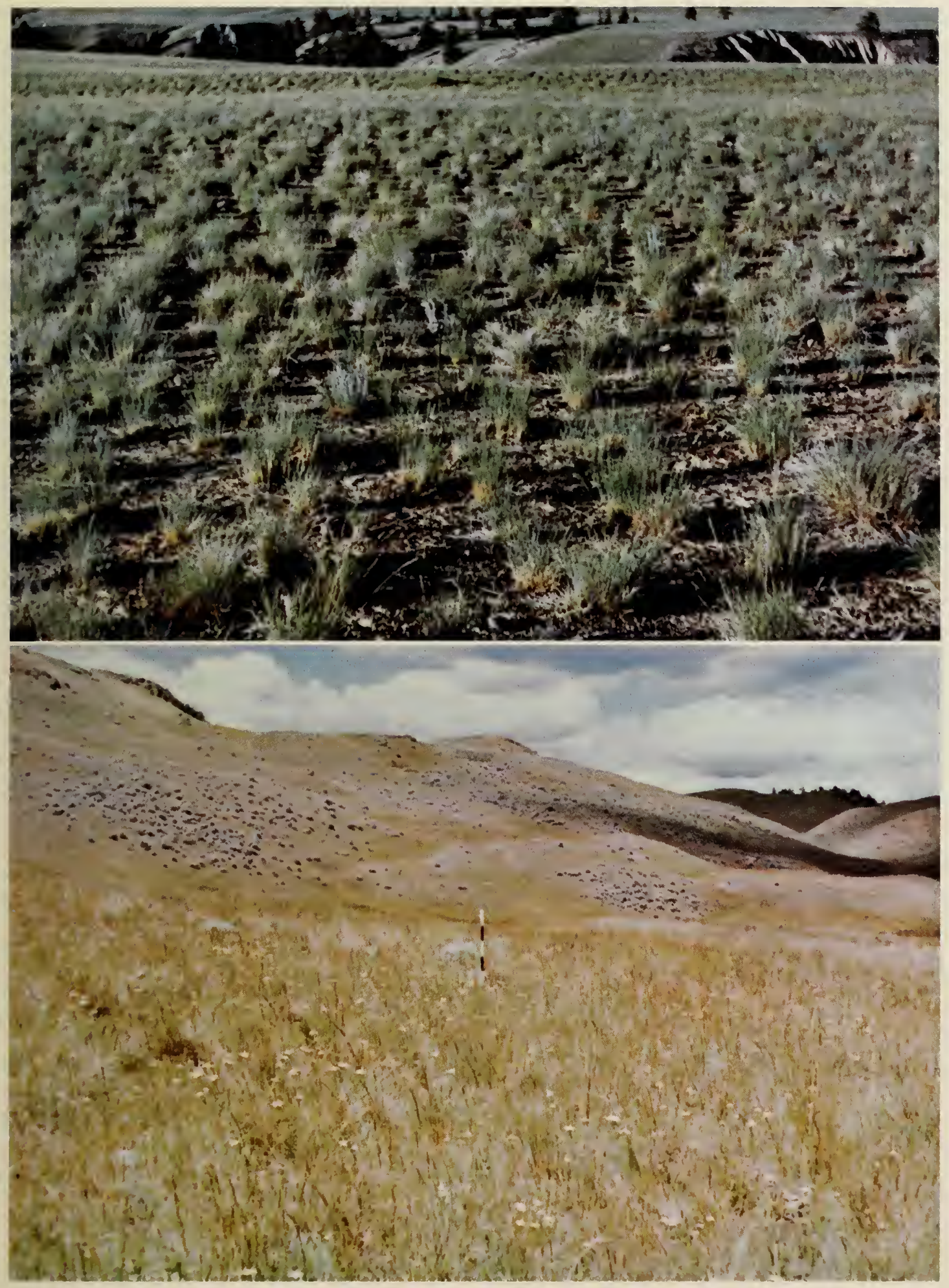

Bluebunch wheatgrass - Sandberg's bluegrass condition classes. Top, excellent. Bottom, good. 


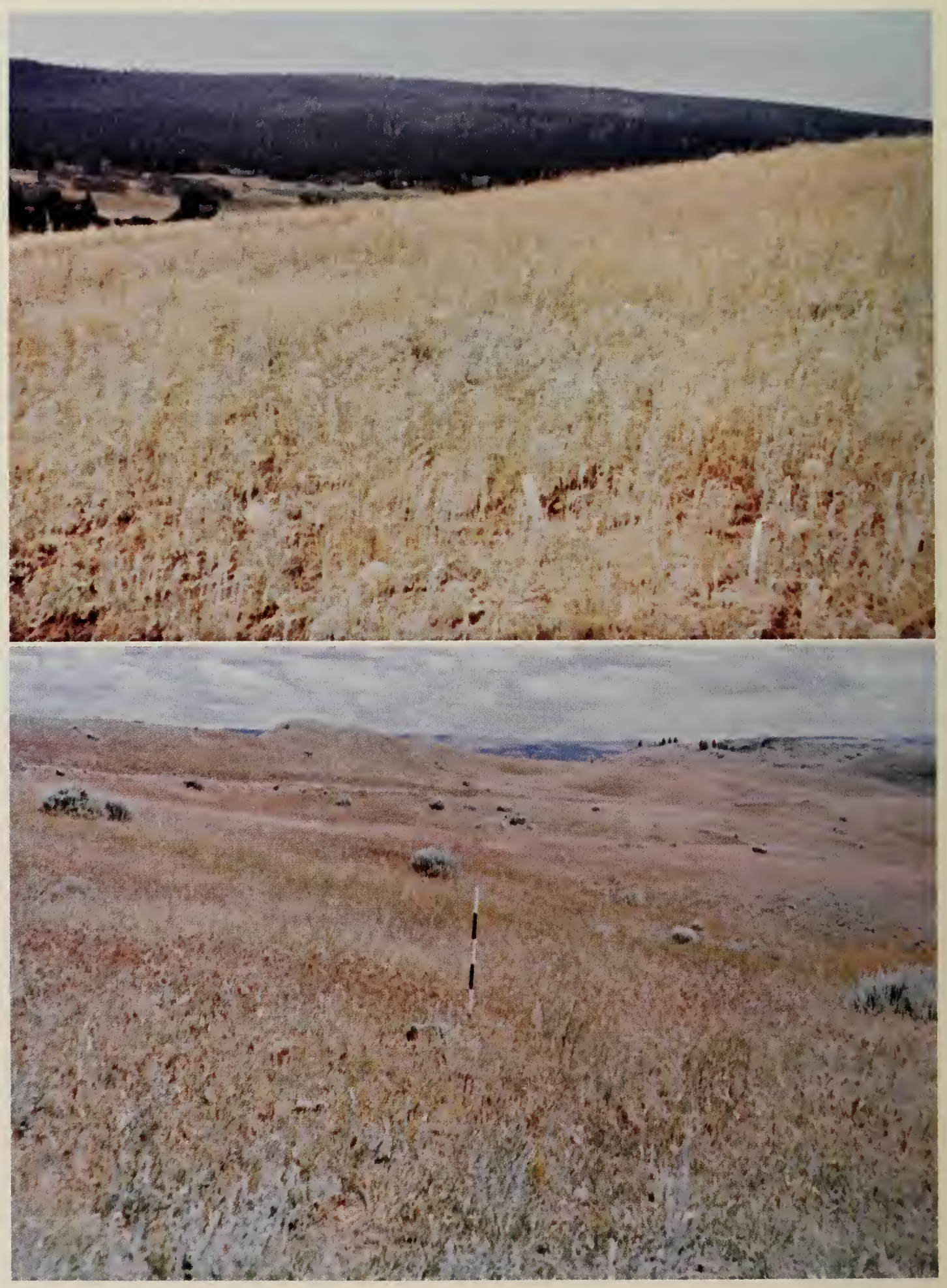

Bluebunch wheatgrass - Sandberg's bluegrass condition classes.

Top, fair. Bottom, poor. 

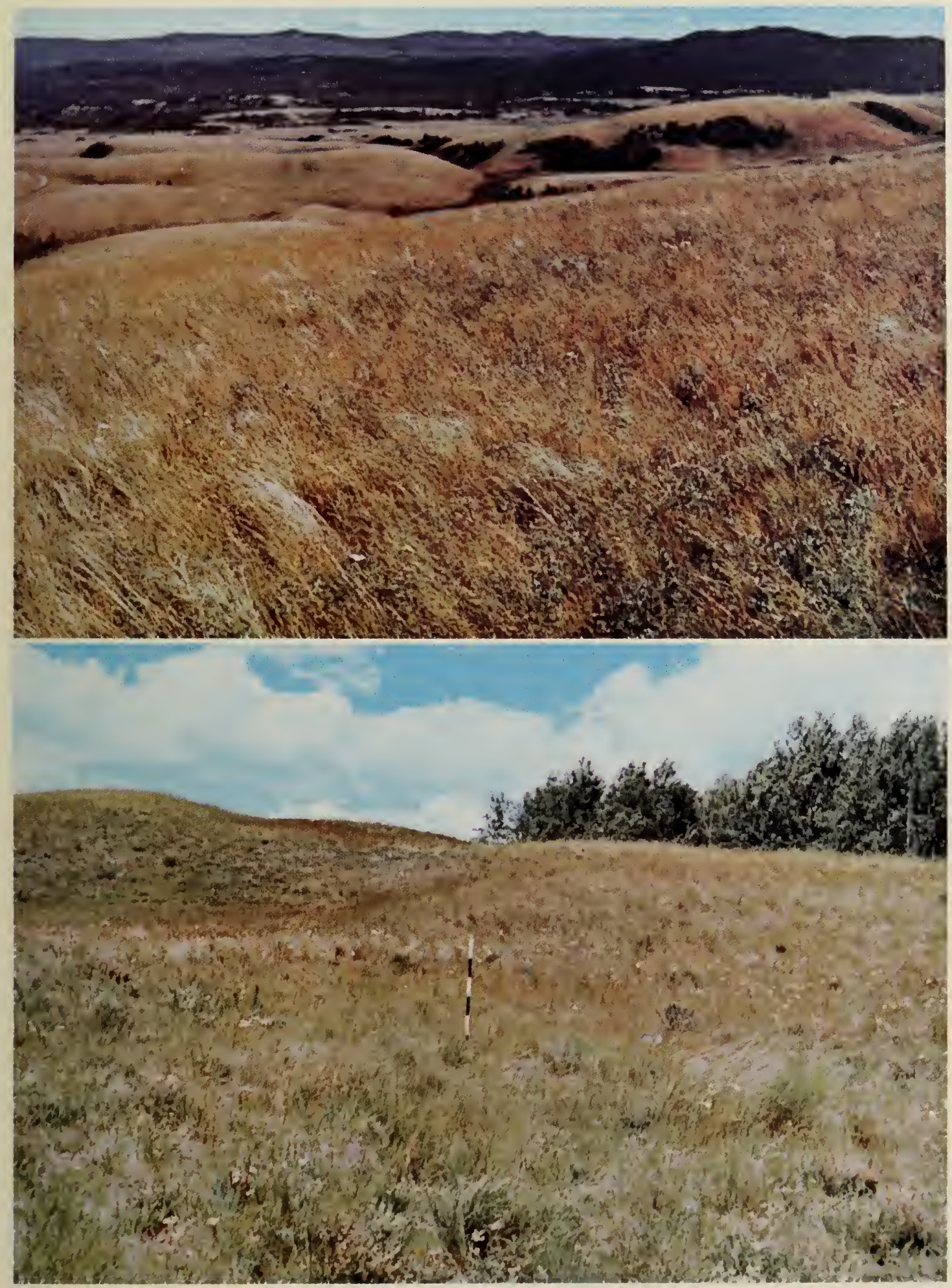

Bluebunch wheatgrass - rough fescue condition classes. Top, excellent. Bottom, good. 


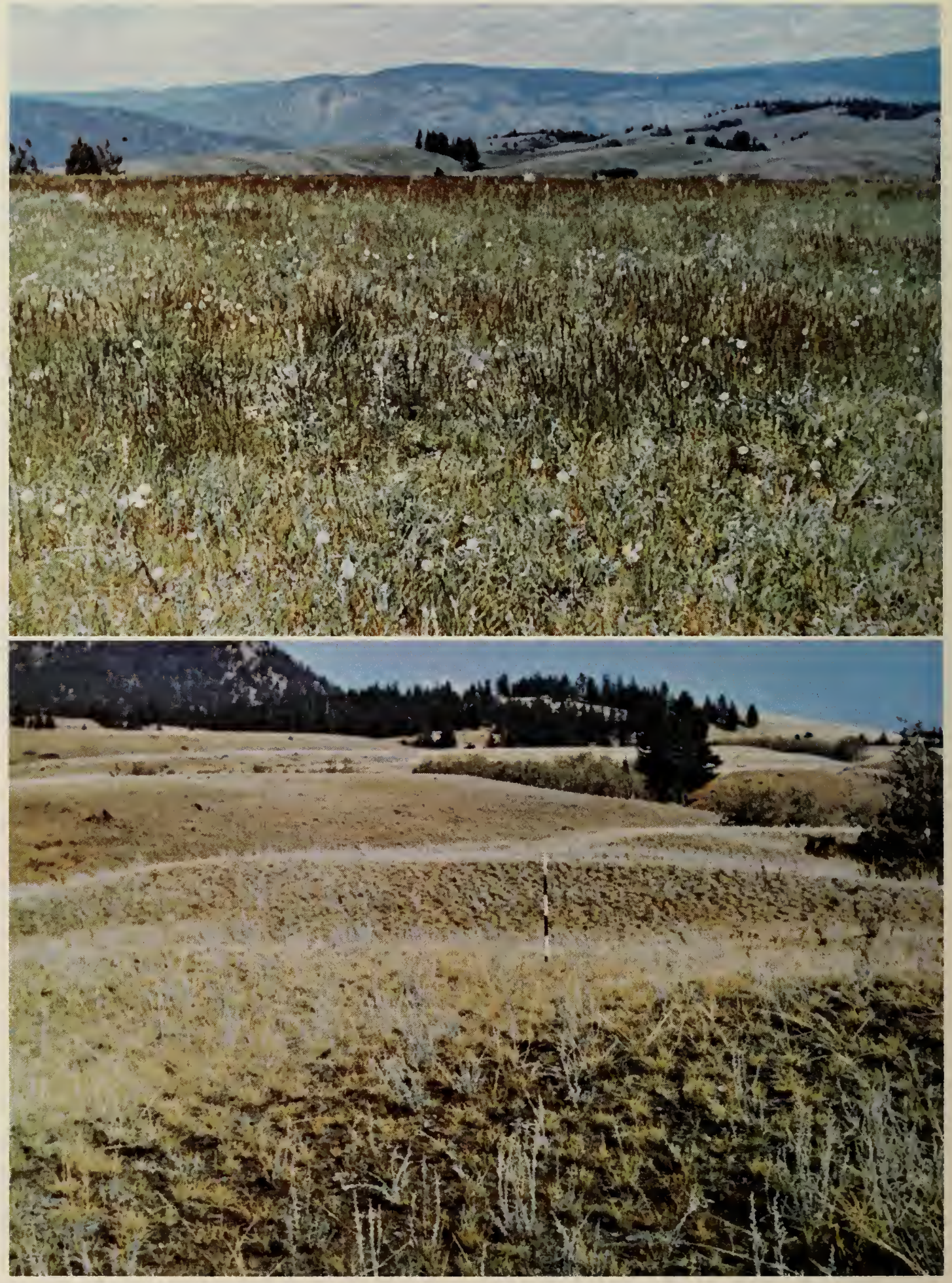

Bluebunch wheatgrass - rough fescue condition classes. Top, fair.

Bottom, fair (needle-and-thread). 


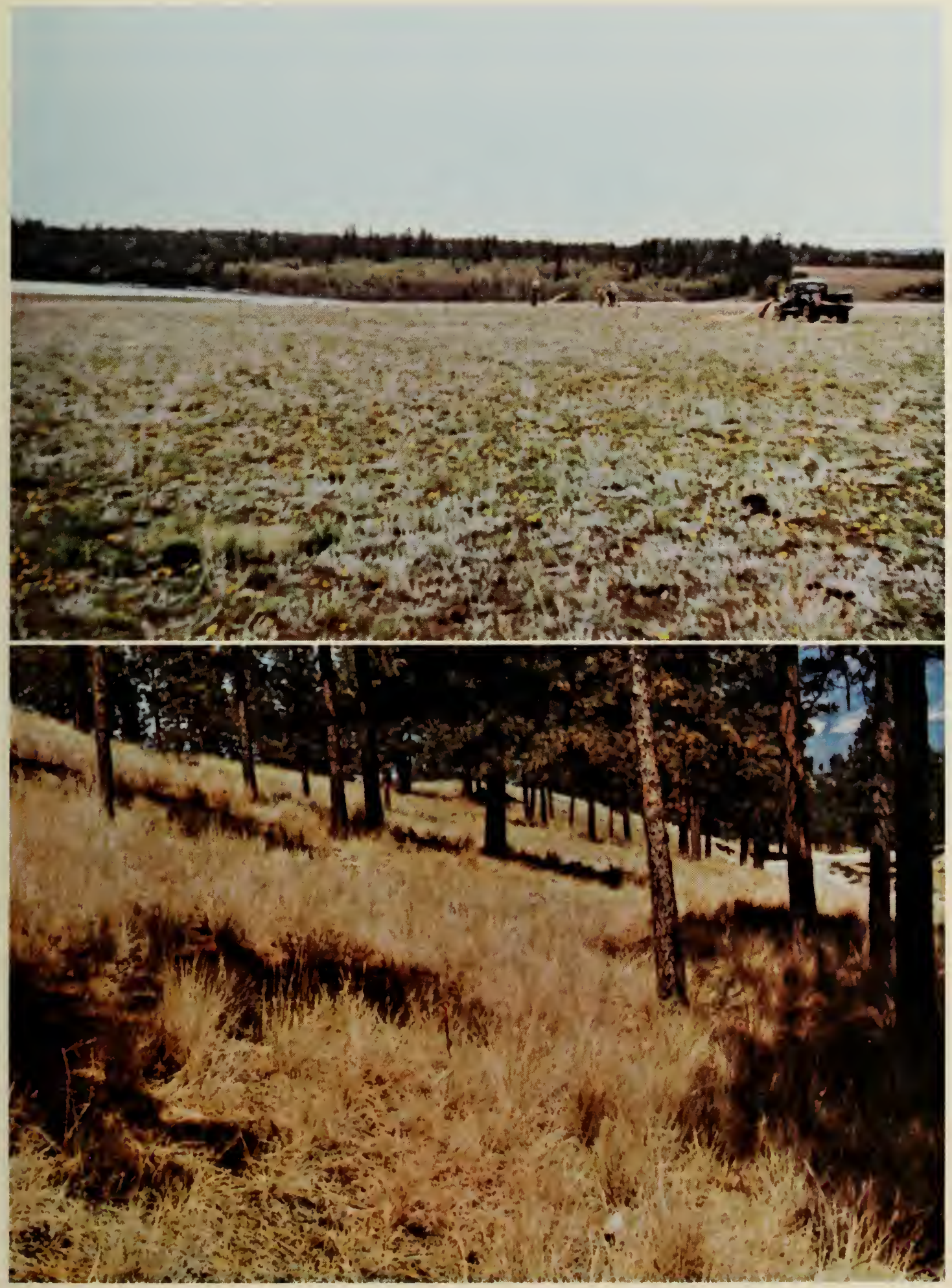

Top, bluebunch wheatgrass - rough fescue condition class, poor. Bottom, ponderosa pine condition class, excellent. 


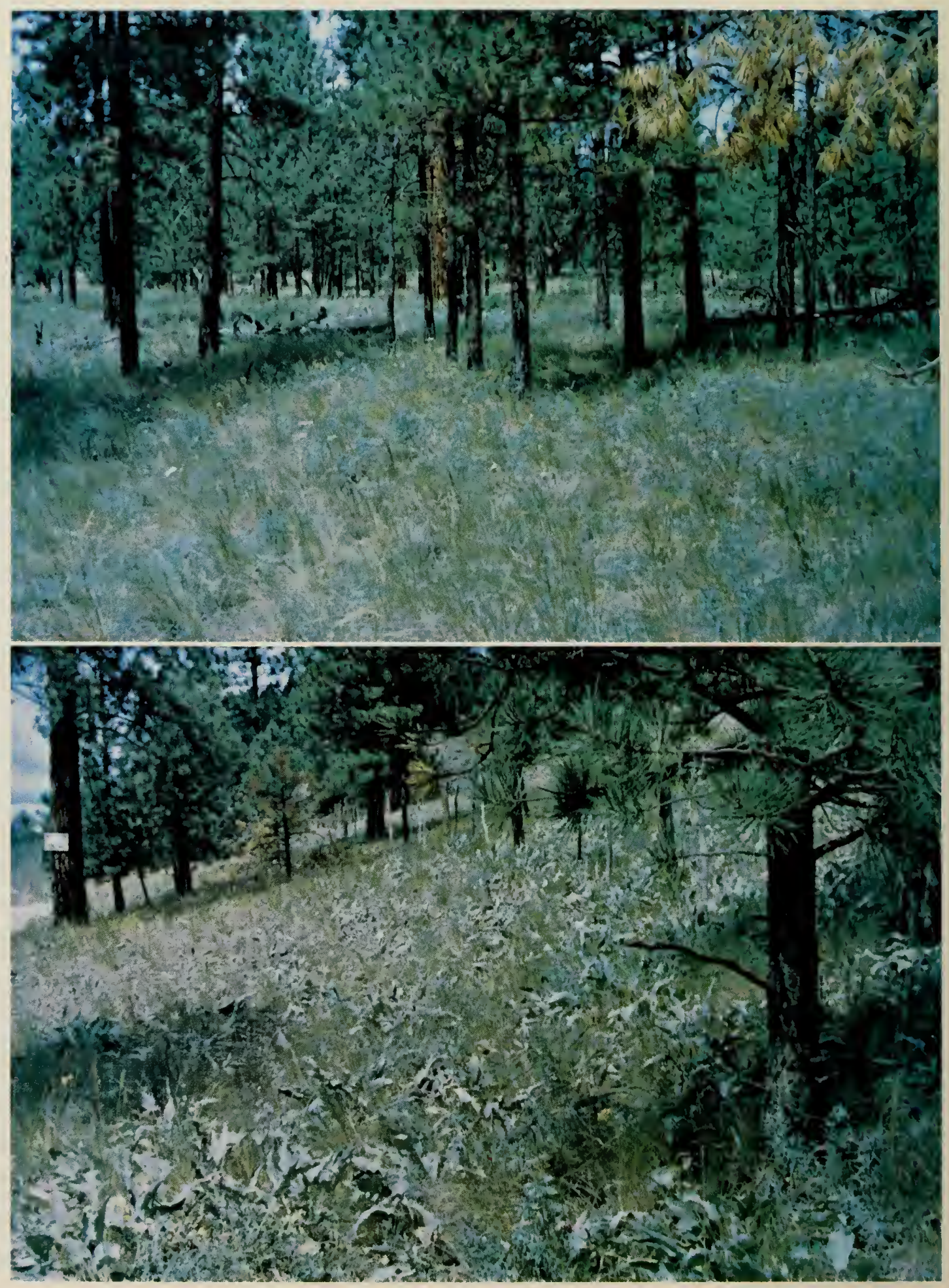

Ponderosa pine condition classes. Top, good. Bottom, fair. 

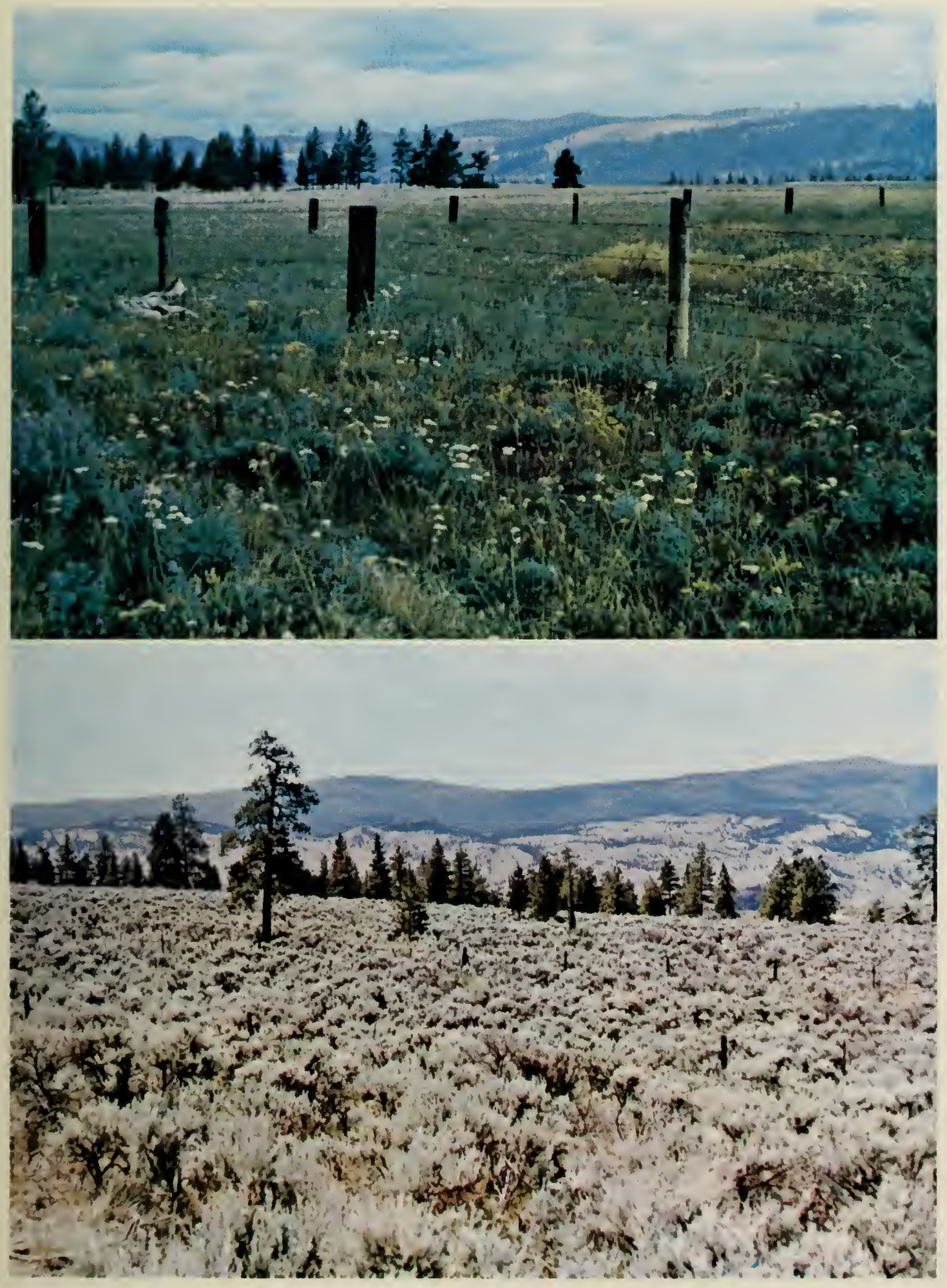

Ponderosa pine condition classes. Top, poor. Bottom, poor (big sagebrush). 


$\begin{array}{lll}\text { Decreasers } & \text { Increasers } & \text { Invaders } \\ \text { Bluebunch wheatgrass } & \text { Balsamroot } & \text { Annual phlox } \\ \text { Idaho fescue } & \text { Big sagebrush (some soils) } & \text { Downy brome } \\ \text { Needle-and-thread } & \text { Dwarf pussytoes } & \text { Dandelion } \\ \quad \text { (some soils) } & \text { Junegrass } & \text { Woolly plantain } \\ \text { Rough fescue } & \text { Needle-and-thread } & \\ & \text { Rabbitbrush } & \\ & \text { Sandberg's bluegrass } & \\ & \text { Silky lupine } & \\ & \text { Western yarrow }\end{array}$

In many cases this site parallels the bluebunch wheatgrass - Sandberg's bluegrass and bluebunch wheatgrass - rough fescue grasslands. It is characterized by the presence of ponderosa pine in open savannalike stands. Hawksbeard, rabbit brush, and balsamroot are more common here than in the other sites. The community occurs, most commonly, on the lower valley slopes.

The productivity of this site is more variable than that of the other sites since the yields in each condition class vary greatly depending on the density of the tree cover. Reestablishment of trees is usually slow after removal because of the relatively dry soil conditions. This zone needs more study before reliable estimates of productivity can be made. The range of forage yields between condition classes overlapped considerably depending on plants and tree-canopy density. The maximum range of all sites was 184 to 890 pounds per acre; the average yield was 428 pounds. The average stocking rate would therefore be about 3 acres per AUM.

\section{MANAGING YOUR RANGES}

You can produce more meat per acre and make more profit per ranch by using your grassland range in the right season and to a safe degree. To do this, however, you must know the growth characteristics and growth requirements of the main forage plants. This information will help you to graze your range so that forage production will be maintained.

\section{PLANT GROWTH CURVE}

To illustrate the principles involved in grass growth the familiar growth curve is used.' This curve shows the rate of growth of the grass plant during the growing season. It is characterized by slow development in the spring, followed by a period of rapidly increasing growth, and then a gradual tapering off in the early summer.

The period of slow development in the spring may cover several weeks, depending on the weather. Because the soil temperatures are too cold for root 
activity at the beginning of this period, the food for plant growth comes from that which was stored in the roots by the plant the previous summer and fall.

When the air and soil temperatures become warmer, nutrients are absorbed from the soil and transported to the green leaves where, in the warm sunlight, they are made into food for plant growth. The increase of leaf growth at this stage in reality increases the capacity of the plant to produce food. This is where the growth curve starts to rise very rapidly.

The rapid rate of top growth continues until the grass begins to form seed stalks. It then begins to taper off, partly because of the increasing demand of seed stalks, flowers, and seed for food. And, as this demand increases and the rate of top growth decreases, the curve flattens out. The onset of dry, hot weather also slows top growth.

Not all of the plant food manufactured in the leaves of the grass goes toward the production of top growth, however. About the time the growth curve starts its rapid rise, the grass begins to build up its store of reserve plant food in the roots and crowns for use early the next year. Then during the period of rapid top growth and seed production, only a little of the plant food goes back into storage. During and after seed maturity, the storage process increases again and continues until growth stops.

In addition to being stored, some of the plant food returned to the roots during the growing season each year goes into the growth of new grass roots, which replace the part of the root system that dies.

As well as producing more forage, grass with adequate stored food survives drought, hard winters, and insect damage better than starved plants.

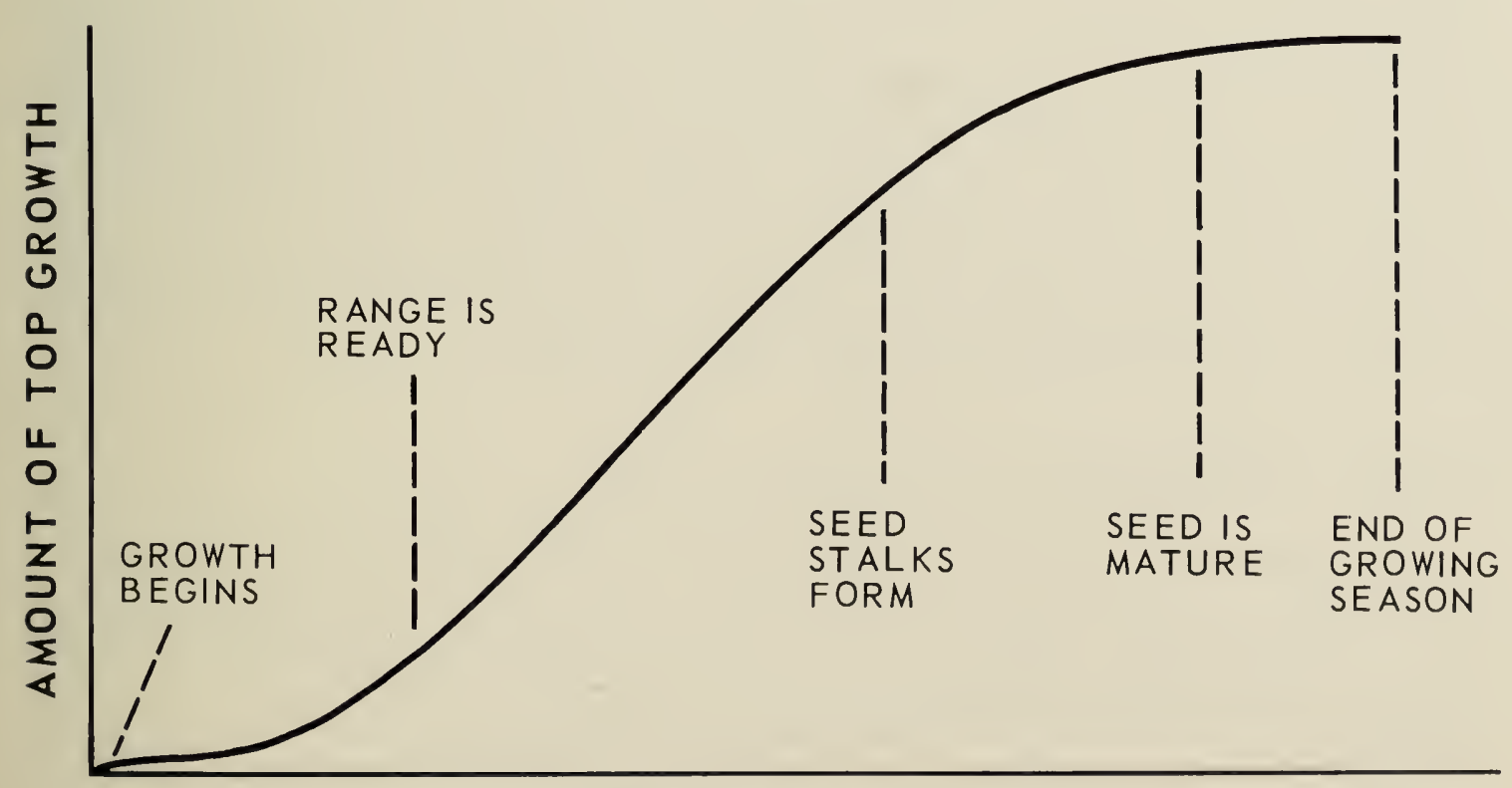




\section{GROWTH CHARACTERISTICS OF GRASS SPECIES}

Different species of range grasses have different growth habits, season of growth, forage yields, chemical compositions, reaction to grazing, and other characteristics.

The different grasses have different periods of growth and best seasons of use. For example, bluebunch wheatgrass starts growth early in the spring, while grasses like sand dropseed have later seasons of use.

Bluebunch wheatgrass is very susceptible to grazing damage at certain times. Analyses at the Research Station at Kamloops show that the plant has its lowest root reserves when the tops are about 7 inches high. From then on, the reserves are built up to provide stored food to start the next year's spring growth. The sugar contents in the roots were 6 percent at 2 inches, 2 percent at 7 inches, 8 percent at full bloom, and 12 percent at seed shed.

Bluebunch wheatgrass should not be grazed before it is 7 inches high if the animals are to be left on until the grass matures. Grazing may be started when the grass is only 4 inches high, but the animals must be removed when the plants have put on no more than half their season's growth. The plants will then have time to grow and store food in their roots for regrowth in the fall and the next spring.

In one test at Kamloops in which bluebunch wheatgrass was clipped at different intensities to simulate grazing, all spring clippings regardless of intensity caused some damage. Plants clipped not later than early May showed the least damage, whereas over 80 percent of the plants clipped at the end of May were killed in one season. The grazing heights mentioned apply only to bluebunch wheatgrass; most other species react differently.

The growth habits of a grass species are important in determining safe degree of use. For example, bluebunch wheatgrass has an erect growth habit whereas needle-and-thread has a spreading growth habit. As a result, close grazing removes many more leaves of bluebunch wheatgrass than needle-and-thread, and fewer green leaves are left to continue manufacturing food. Measurements from ranges near Kamloops show that clipping bluebunch wheatgrass 5 inches above the ground when fully grown removes about 70 percent of the plant, whereas clipping needle-and-thread at the same height removes only about 45 percent. For most grasses it is best to leave at least half of the total season's growth to ensure adequate food reserves in the plant.

\section{RANGE READINESS AND PROPER USE}

For proper'seasonal use delay grazing in the spring until about the time the grass begins to grow rapidly. At this stage the grass is no longer dependent mainly on the limited supply of plant food stored in the roots. It is now able to obtain raw materials from the soil. If grazing begins at an earlier date and the tops are kept eaten off, the natural growth cycle of the grass plant is delayed and the plant may never be able to produce food for storage. 
Grassland range in the dry belt is ready for grazing by the time the bluebunch wheatgrass is about 7 inches high. In the Kamloops area this varies from about April 8 on the lower ranges (1100 to 1700 feet) to about May 10 on the higher grasslands (2300 to 2800 feet).

By the time the bluebunch wheatgrass is 6 to 7 inches tall, rough fescue is at the same height, needle-and-thread is about 3 inches high, Sandberg's bluegrass and balsamroot are starting to head out, and the Johnny-jump-up flowers are withered.

Some top growth should be left at the end of the grazing period. During the growing season this gives the plant some leaf growth to continue food manufacture while moisture is still available in the soil. In the fall old leaves and seed stalks that remain protect the soil and conserve moisture. The amount of ungrazed material required to accomplish this varies with such factors as type of soil and rainfall pattern.

To repeatedly violate these requirements of grass growth by grazing too early and keeping the grass grazed down too closely during the growing season will result in a weakening of the plants and deterioration of site condition and forage production.

\section{RANGE CONDITION}

When these principles are ignored, the good forage species such as bluebunch wheatgrass and rough fescue disappear and are replaced by other plants such as Sandberg's bluegrass, downy brome, pasture sage, big sagebrush, and pussytoes. The range then goes down in condition.

Fence-line differences often show these changes dramatically. One site studied contained 50 percent wheatgrass and 7 percent big sagebrush and yielded 1500 pounds of grass per acre, whereas the adjacent grazed range had 5 percent wheatgrass and 35 percent big sagebrush and yielded only 140 pounds per acre. Another area that has had only incidental grazing at any time had 70 percent bluebunch wheatgrass and 13 percent big sagebrush and produced 700 pounds of feed per acre. On the adjacent heavily grazed side of the fence there was only 7 percent bluebunch wheatgrass but 25 percent big sagebrush, which yielded only 90 pounds per acre. A site that may never have been grazed by stock contained 80 percent bluebunch wheatgrass and practically no cactus, big sagebrush, or downy brome; it yielded nearly 550 pounds of grass per acre. But across the fence on an abandoned field there was 6 percent bluebunch wheatgrass, 47 percent downy brome, 22 percent cactus, and 11 percent sagebrush, which produced only 50 pounds of grass per acre.

\section{RANGE RECOVERY TIME}

Some areas recover quickly from overgrazing while others may take generations. One area fenced in 1923 near Riske Creek has shown a recovery of bluebunch wheatgrass from 4 percent to 13 percent, and a decrease in pasture sage 
from 36 percent to 13 percent with relatively little improvement in yield. Another area near Tranquille fenced in 1936 has shown a recovery of bluebunch wheatgrass from 28 percent to 58 percent and a decrease in needle-andthread from 17 percent to 1 percent. The average yield has increased from 164 pounds of forage per acre to 360 pounds. A third area on the Skookumchuck prairie fenced in 1952 has shown an increase in bluebunch wheatgrass from 7 percent to 25 percent and a decrease in pussytoes from 26 percent to 10 percent.

The feed value of range forage is an important consideration in season of use. For example, it is sometimes possible to graze a range high in broadleaved plants early in the season to take advantage of the feed produced by these species before they dry up and disappear. More information is given in the publications Chemical Composition of Native Forage Plants in British Columbia in Relation to Grazing Practices, and Handbook on Grazing Values of Range Plants of British Columbia, available from the Research Station at Kamloops.

\section{POINTS TO REMEMBER}

For proper range management

- graze moderately during the growing season, leaving enough top growth for manufacture and storage of food, and protection for the plant crowns;

- rest the range after close grazing at any time in the growing season to allow growth to resume and plant food to be stored in the roots. 




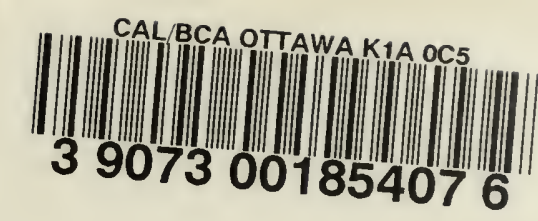


Copies of this publication may be obtained from:

INFORMATION DIVISION

CANADA DEPARTMENT OF AGRICULTURE

OTTAWA

ROGER DUHAMEL, F.R.S.C., QUEEN'S PRINTER AND CONTROLLER OF STATIONERY, OTTAWA, 1968 